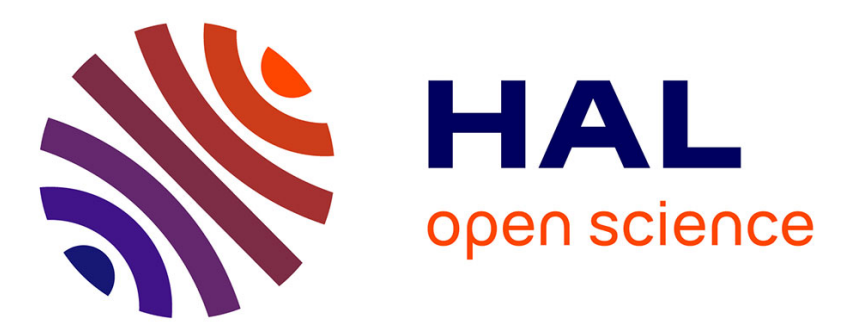

\title{
Electrospray ionization: an efficient approach to deposit polymetallic molecular switches onto gold surfaces
}

Amina Benchohra, Christophe Méthivier, Jessem Landoulsi, David Kreher, Rodrigue Lescouëzec

\section{- To cite this version:}

Amina Benchohra, Christophe Méthivier, Jessem Landoulsi, David Kreher, Rodrigue Lescouëzec. Electrospray ionization: an efficient approach to deposit polymetallic molecular switches onto gold surfaces. Chemical Communications, 2020, 56 (48), pp.6587-6589. 10.1039/D0CC01906B . hal02879959

\section{HAL Id: hal-02879959 \\ https://hal.sorbonne-universite.fr/hal-02879959}

Submitted on 24 Jun 2020

HAL is a multi-disciplinary open access archive for the deposit and dissemination of scientific research documents, whether they are published or not. The documents may come from teaching and research institutions in France or abroad, or from public or private research centers.
L'archive ouverte pluridisciplinaire HAL, est destinée au dépôt et à la diffusion de documents scientifiques de niveau recherche, publiés ou non, émanant des établissements d'enseignement et de recherche français ou étrangers, des laboratoires publics ou privés. 


\section{Electrospray lonization: an efficient approach to deposit polymetallic molecular switches onto gold surfaces}

JessemReceived 00th January 20xx,

Accepted 00th January 20xx

\author{
Amina Benchohra, ${ }^{\mathrm{a}}$ Christophe Méthivier, ${ }^{\mathrm{b}}$ Jessem Landoulsi, ${ }^{\mathrm{b} *}$ David Kreher, ${ }^{* a}$ and Rodrigue \\ Lescouezec*a
}

DOI: $10.1039 / \times 0 \times x 00000 x$

\begin{abstract}
Electrospray ionization (EI) deposition is proven efficient in obtaining monolayers of a polymetallic charge transfer complex onto gold surfaces. The molecule's integrity is monitored by PM-IRRAS and XPS. This approach broadens the perspective of molecular magnetic switches' deposition, which is currently dominated by thermal evaporation technique of monometallic spin crossover (SCO) complexes.
\end{abstract}

Molecular switches, which can undergo reversible changes of their electronic properties under external perturbation, are attracting strong research interests because of their potential application in molecule-based nanodevices. ${ }^{1-4}$ In particular, magnetic switches such as spin-crossover, ${ }^{5}$ charge-transfer ${ }^{6}$ and valence tautomeric complexes, ${ }^{7}$ whose spin-state can be controlled by light, pressure, temperature, electric and magnetic fields, open opportunities in molecular spintronics. ${ }^{8}$ In this context, strong efforts have been devoted to the deposition of these complexes onto surfaces as this can represent a first stage in the device's construction. Over the last decade, the vacuum thermal evaporation has stood out as the dominant approach for the deposition of molecular multilayers, monolayers or sub-monolayers of neutral monometallic spincrossover complexes onto various substrates. Some of these studies led to the creation of interesting nano-electronic devices. ${ }^{9,10}$ However, the vacuum evaporation (via sublimation) approach successfully used for SCO complexes can hardly be extended to heavier and charged polymetallic complexes because large molecules can disassemble during the process or form aggregates on the surface. In such cases, wet chemistry approaches (such as drop casting, spin coating) can be used, and

\footnotetext{
a. Institut Parisien de Chimie Moléculaire, UMR CNRS 8232, Sorbonne Université, 4 place Jussieu, 750005 Paris, France.E-mail :david.kreher@upmc.fr, rodrigue.lescouezec@upmc.fr

b. Laboratoire de Réactivité de Surface, UMR CNRS XXXX, Sorbonne Université, 4 place Jussieu, 75005, Paris, France.E-mail : jessem.landoulsi@upmc.fr

Electronic Supplementary Information (ESI) available: [details of any supplementary information available should be included here]. See DOI: 10.1039/x0xx00000x
}

they usually lead to thin films of micro/nano-metric size. However, wet-deposition approaches require coping with the ubiquitous presence of organic contaminants on the inorganic solid surfaces, which is due to their high surface energy. ${ }^{11}$ In particular, the omnipresence of the adventitious contaminants considerably limits the selectivity of the characterization of the organic adlayer of interest. ${ }^{12}$ More sophisticated methods have to be used to target (sub)monolayer of mono/polymetallic magnetic switches on surfaces. For example, polymetallic photomagnetic charge transfer complexes were deposited onto surfaces using the Langmuir-Blodgett method, ${ }^{13}$ while selfassembled monolayers of valence tautomeric complexes could be obtained by functionalizing a ligand with an anchoring group. ${ }^{14}$ Overall, these examples of successful monolayer deposition remain scarce although the properties of the polymetallic complexes are very attractive. In fact, besides showing multi-responsive behaviour ${ }^{15}$ like the SCO complexes, we recently showed that some charge transfer switches also exhibit a multi-redox flexibility, ${ }^{16,17}$ which make them attractive for the design of charge-storage molecule-based devices. ${ }^{3,18}$ In particular photomagnetic cyanide-bridged $A \subset\left\{\mathrm{Fe}_{4} \mathrm{CO}_{4}\right\}$ cubes can show up to nine reversibly accessible redox states ( $A$ is an inserted alkali ion). ${ }^{19}$ The search for reliable routes for depositing these polymetallic functional molecules is crucial to fully explore their potential in molecular electronics. In this context, we decided to explore the electrospray ionisation (EI). Indeed, EI was already proven efficient for depositing either organic molecules, ${ }^{20}$ peptides, $^{21}$ SCO and magnetic complexes 22,23 or even single molecule magnets onto surfaces. ${ }^{24,25}$ Here El was successfully applied to deposit a soluble and robust $\mathrm{Cs} \subset\left\{\mathrm{Fe}_{4} \mathrm{CO}_{4}\right\}$ molecular switch as (sub)monolayer.

The investigated complex, of formula $\mathrm{CsC}$ $\left\{\left[\mathrm{Fe}(\mathrm{Tp})(\mathrm{CN})_{3}\right]_{4}\left[\mathrm{Co}\left({ }^{\mathrm{TPh} T p}\right)\right]_{4}\right\} \mathrm{ClO}_{4}$ (noted from now $\mathrm{Cs} \subset\left\{\mathrm{Fe}_{4} \mathrm{CO}_{4}\right\}$ ) is an octametallic cubic cage where cyanide ligands act as edges (Fig. 1). It is obtained by the self-assembly of the $\left[\mathrm{Fe}^{\prime \prime \prime}(\mathrm{Tp})(\mathrm{CN})_{3}\right]^{-}$ precursor $\left(\mathrm{Tp}=\right.$ hydrotris (pyrazolylborate)) with $\mathrm{Co}^{\prime \prime}\left(\mathrm{ClO}_{4}\right)_{2}$ and $\mathrm{CsClO}_{4}$ salts and a blocking ligand of the Tp family, where the 
proton linked to the boron in Tp is replaced by a thiophene-aryl group (noted ${ }^{\mathrm{TPh} T \mathrm{~T}}$ ). As observed in our previous studies on similar cages, a metal-to-metal charge transfer occurs in solution. ${ }^{19}$ The cubic molecule is thus isolated here in its $\mathrm{Cs} \subset\left\{\mathrm{Fe}{ }_{4} \mathrm{Co}^{\prime \prime \prime}{ }_{4}\right\}$ diamagnetic state, as shown by the magnetic measurements and the NMR data (see ESI). In these cubic complexes, the central caesium ion occupies the cubic cavity and interacts with the twelve cyanide edges, conferring a remarkable stability to the polymetallic complex. It was not possible to obtain single crystal suitable for X-ray diffraction, however the actual molecule composition was checked by elemental analysis, ${ }^{1} \mathrm{H},{ }^{13} \mathrm{C}\left(1 \mathrm{D}\right.$ and $2 \mathrm{D}$ ) and ${ }^{133} \mathrm{Cs}$ NMR (details in ESI). For example, the ${ }^{133} \mathrm{Cs} N \mathrm{NR}$ spectrum shows a unique peak corresponding to the inserted alkali ion. Finally, the highresolution mass spectrometry experiment shows a molecular

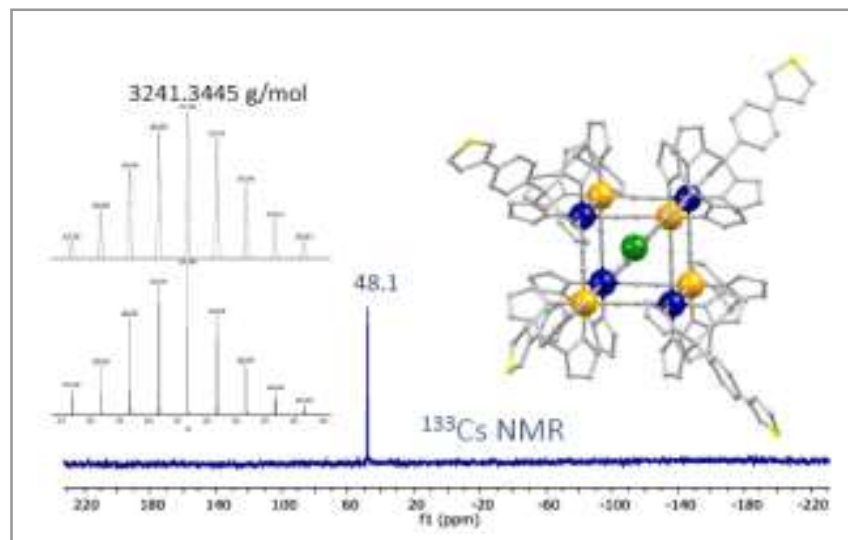

Fig. 1. Scheme of the $\mathrm{Cs} \subset\left\{\mathrm{Fe}_{4} \mathrm{CO}_{4}\right\}$ switchable cube (Fe : orange; Co: violet, Cs: green, $\mathrm{S}$ : yellow, $\mathrm{C}, \mathrm{N}$ and $\mathrm{B}$ : grey) together with the zoom of the mass spectrogram (experimental and simulated) and the ${ }^{133} \mathrm{Cs}$ NMR spectrum.

peak at $3241.3 \mathrm{~g} / \mathrm{mol}$ whose isotopic pattern perfectly matches with the simulated one (Fig. S1, details in ESI).

The deposition of $\mathrm{Cs} \subset\left\{\mathrm{Fe}_{4} \mathrm{Co}_{4}\right\}$ molecules on a (111) gold substrate through $\mathrm{EI}$ was performed from a solution in 1,2dichloroethane at $5.10^{-4} \mathrm{M}$, as described in the ESI. During EI deposition, the partial pressure in the main chamber was around $10^{-7}$ Torr. In these experimental conditions (solvent and concentration), the molecules were shown to preserve their molecular structure as demonstrated by the comparison of the infrared spectroscopy studies and the XPS analyses on the bulk and on the surface.

The infrared (IR) spectroscopy is a well-adapted technique for the structural and electronic characterization of cyanido-based coordination complexes. ${ }^{26}$ Actually, the cyanide stretching vibration, $v_{\mathrm{CN}}$, which shows strong absorption in an unpopulated region of the IR spectra (between 2000- $2300 \mathrm{~cm}$ $\left.{ }^{1}\right)$, is very sensitive to both the metal oxidation state and the coordination mode of the cyanide ligand. For example, $v_{\mathrm{CN}}$ vibration of non-bridging Fe"ll-CN moieties typically occurs below ca. $2080 \mathrm{~cm}^{-1}$ while bridging ones occurs up to $c a .2135 \mathrm{~cm}^{-1}$. In the present case the IR spectrum of the $\mathrm{Cs} \subset\left\{\mathrm{Fe}_{4} \mathrm{CO}_{4}\right\}$ cube recorded on a crystalline powder (Fig. 2B) features two intense cyanide stretching vibrations at 2104 and $2124 \mathrm{~cm}^{-1}$, which are associated to the $\mathrm{Fe}{ }^{\mathrm{I}}-\mathrm{C} \equiv \mathrm{N}-\mathrm{Co}^{\prime \prime \prime}$ linkages. These stretching vibrations are actually very close to those observed in related
$\left\{\mathrm{Fe}_{2} \mathrm{CO}_{2} \mathrm{II}_{2}\right\}$ square complexes (at 2109 and $2126 \mathrm{~cm}^{-1}$ )..$^{27}$ Interestingly, the IR pattern measured in-situ by PM-IRRAS after El deposition on $\mathrm{Au}(111)$ substrate (Fig. $2 \mathrm{C}$ ) reveals a spectral feature identical to that of the cubes prior to deposition. The two contributions of cyanide bridges are observed at 2109 and

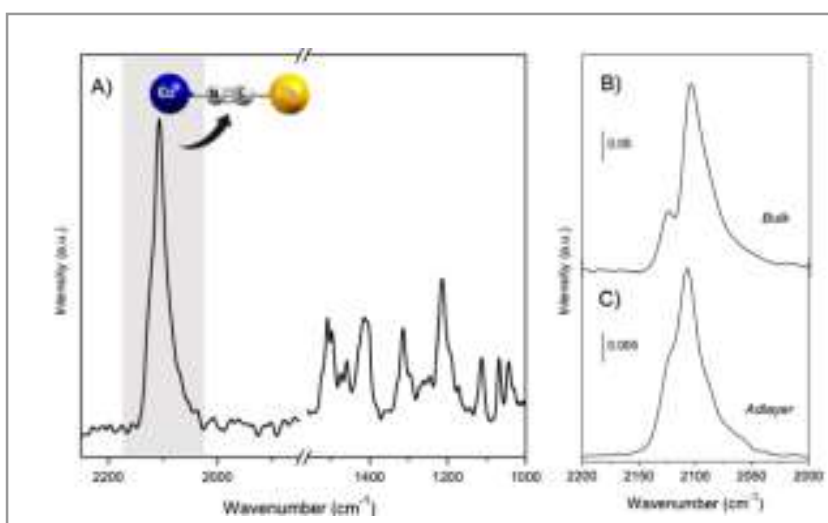

Fig. 2. A) PM-IRRAS spectrum of the $\mathrm{Cs} \subset\left\{\mathrm{Fe}_{4} \mathrm{CO}_{4}\right\}$ cube deposited on $\mathrm{Au}(111)$ in the $900-3100 \mathrm{~cm}^{-1}$ range, $\mathrm{B}$ ) zoom on $\mathrm{CN}$ stretching band, C) comparison with the FT-IR spectrum on the bulk.

$2124 \mathrm{~cm}^{-1}$, indicating that their chemical/electronic environment is preserved in the adsorbed state.

The Fe(II) oxidation state in the bulk sample is also confirmed by the $v\{B-H\}$ stretching at $2483 \mathrm{~cm}^{-1}$ (Fig. $2 A$ ), which is typical of the $\left[\mathrm{Fe}^{\prime \prime}(\mathrm{Tp})(\mathrm{CN})_{3}\right]$ moieties and which contrasts with that of the $\left[\mathrm{Fe}^{\prime \prime \prime}(\mathrm{Tp})(\mathrm{CN})_{3}\right]$ generally observed above $2500 \mathrm{~cm}^{-1}$ (for example at ca. $2509 \mathrm{~cm}^{-1}$ in the $\mathrm{Bu}_{4} \mathrm{~N}\left[\mathrm{Fe}^{\prime \prime \prime}(\mathrm{Tp})(\mathrm{CN})_{3}\right]$ precursor).

The integrity of the cubic cages once deposited onto surfaces was also checked by the XPS study (Fig. 3). Analyses were first performed on the $\mathrm{Cs} \subset\left\{\mathrm{Fe}_{4} \mathrm{CO}_{4}\right\}$ bulk. Figure 3 displays the expected Co $2 p$ Fe $2 p$ and $C s 3 d$ peaks constituting the molecular cage. The Co $2 p$ doublet shows a Co $2 p_{3 / 2}$ peak with a single contribution at $783.0 \mathrm{eV}$, and a distance between the Co $2 p_{3 / 2}$ and Co $2 p_{1 / 2}$ peaks equal to $15.0 \mathrm{eV}$ (Fig. $3 \mathrm{~A}$ ). This is consistent with the occurrence of the $\mathrm{Co}$ (III) oxidation state, as reported for other organometallic complexes. ${ }^{28}$ The main $\mathrm{Fe}$ $2 p_{3 / 2}$ contribution shows a narrow peak $(F W H M=1.1 \mathrm{eV})$ at $708.9 \mathrm{eV}$ (Fig. 3B), which is assigned to Fe(II) compounds. ${ }^{29}$ The two times less intense Fe $2 \mathrm{p}_{1 / 2}$ peak ( $721.7 \mathrm{eV}$ ) overlaps with the $C_{s} 3 d_{5 / 2}$ peak but both contributions remain distinguishable. All these spectral features are fully consistent with the electronic states expected for $\mathrm{Co}$, Fe and Cs elements.

Figure 3 also presents typical Co $2 p$, Fe $2 p$ and Cs $3 d$ peaks constituting the molecular cage recorded on the gold surface after El deposition. Remarkably, the Co $2 p$ doublet shows a main Co $2 p_{3 / 2}$ contribution at $783.0 \mathrm{eV}$ and a distance between Co $2 p_{3 / 2}$ and Co $2 p_{1 / 2}$ peaks equal to $15.0 \mathrm{eV}$ (Fig. $3 \mathrm{C}$ ), identical to that observed on the $\mathrm{Cs} \subset\left\{\mathrm{Fe}_{4} \mathrm{CO}_{4}\right\}$ bulk (Fig. 3A). A broad contribution at lower binding energy $(781.0 \mathrm{eV})$ was also observed, accompanied with satellites at higher binding energies (around $788.0 \mathrm{eV}$ ). This is likely due to the presence of a small amount of $\mathrm{Co}(\mathrm{II})$ compound. Such reduction is possible as this family of $\mathrm{Cs} \subset\left\{\mathrm{Fe}_{4} \mathrm{CO}_{4}\right\}$ cubes can be obtained either in a diamagnetic state or in a paramagnetic state (as a neutral molecule with one reduced $\mathrm{Co}(\mathrm{II})) .{ }^{16}$ The stabilization of one state or the other depends on the nature of the blocking 
ligand. ${ }^{30}$ The Fe $2 p$ doublet (Fig. 3D) exhibits a main Fe $2 p_{3 / 2}$ contribution at $708.8 \mathrm{eV}$ identical to that observed the $\mathrm{Cs} \subset\left\{\mathrm{Fe}_{4} \mathrm{CO}_{4}\right\}$ bulk (Fig. 3B), thus confirming their assignment to
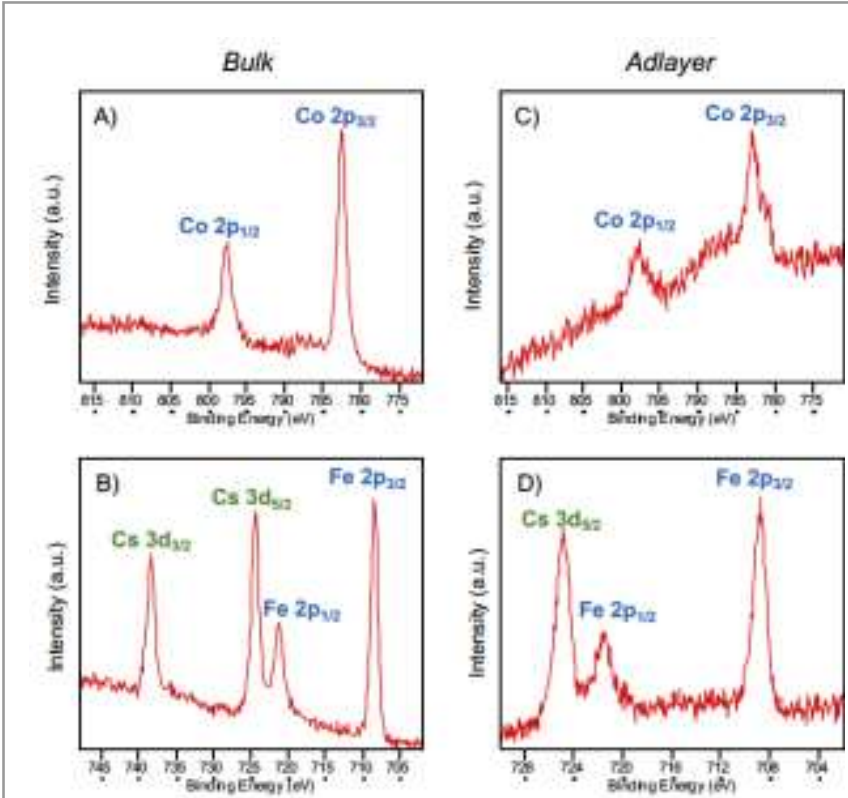

Fig. 3. XPS spectra of the $\mathrm{Cs}\left\{\mathrm{Fe}_{4} \mathrm{CO}_{4}\right\}$ cube in the bulk (A and $\mathrm{B}$ ) and on the surface ( $C$ and $D$ ).

Fe(II) compounds. Also, Cs $3 d_{5 / 2}$ (Fig. 3B) shows the typical spectrum due to $\mathrm{Cs}^{+}$species.

XPS Au $4 f$ spectra recorded prior to and after the deposition of $\mathrm{Cs} \subset\left\{\mathrm{Fe}_{4} \mathrm{CO}_{4}\right\}$ through $\mathrm{El}$ technique showed significant signal attenuation without any noticeable chemical shift (Fig. S8). This indicates the presence of an adlayer on the gold surface, as expected: by considering the electron inelastic mean free paths (IMFP) calculation detailed in ESI and the attenuation of the $\mathrm{Au}$ signal, this yields an adlayer with a mean thickness of about 2.1 $\mathrm{nm}$. This estimate is perfectly consistent with the dimension of $\mathrm{Cs} \subset\left\{\mathrm{Fe}_{4} \mathrm{CO}_{4}\right\}$ molecule (ca. 15-20 $\mathrm{A}$ ) and suggests the formation of a monolayer-like structure on the gold surface.

In summary, the El technique allowed the deposition of a $\mathrm{Cs} \subset\left\{\mathrm{Fe}_{4} \mathrm{CO}_{4}\right\}$ cube, which belongs to a family of photo- and electro-switchable molecules, onto a gold substrate. This approach appears as a straightforward, yet powerful means for the preparation of monolayers of polymetallic molecular switches, while avoiding adventitious organic contaminations. By combining in-situ characterization and ex-situ analysis in ultra-high vacuum we showed that El technique preserves the molecular structure of the studied molecules (IR) and the degree of oxidation states of the metals (XPS) in the adsorbed state. $\mathrm{El}$ is thus an alternative to wet-solution approaches that have been previously explored for polymetallic species and the vapour evaporation technique, which is still largely used on monometallic SCO switches. Future studies will aim at (i) evaluating the flexibility of this approach for depositing other polymetallic molecular switches; (ii) investigating the photo/electro-switching properties of the deposited molecules through advanced physical measurement.

\section{Conflicts of interest}

There are no conflicts to declare.

\section{Notes and references}

1 B. L. Feringa, Ed., Molecular switches, Wiley-VCH-Verl, Weinheim, 2011.

2 J. L. Zhang, J. Q. Zhong, J. D. Lin, W. P. Hu, K. Wu, G. Q. Xu, A. T. S. Wee and W. Chen, Chemical Society Reviews, 2015, 44, 29983022.

$3 \mathrm{~J} . \mathrm{S}$. Lindsey and D. F. Bocian, Accounts of Chemical Research, 2011, 44, 638-650.

4 G. Molnár, S. Rat, L. Salmon, W. Nicolazzi and A. Bousseksou, Advanced Materials, 2018, 30, 1703862.

5 M. A. Halcrow, Ed., Spin-crossover materials: properties and applications, Wiley, Chichester, 2013.

6 Y.-S. Meng, O. Sato and T. Liu, Angewandte Chemie International Edition, 2018, 57, 12216-12226.

7 T. Tezgerevska, K. G. Alley and C. Boskovic, Coordination Chemistry Reviews, 2014, 268, 23-40.

8 E. Coronado, Nat Rev Mater, , DOI:10.1038/s41578-019-0146-8.

9 T. Miyamachi, M. Gruber, V. Davesne, M. Bowen, S. Boukari, L. Joly, F. Scheurer, G. Rogez, T. K. Yamada, P. Ohresser, E. Beaurepaire and W. Wulfhekel, Nature Communications, DOI:10.1038/ncomms1940.

10 C. Lefter, S. Rat, J. S. Costa, M. D. Manrique-Juárez, C. M. Quintero, L. Salmon, I. Séguy, T. Leichle, L. Nicu, P. Demont, A. Rotaru, G. Molnár and A. Bousseksou, Advanced Materials, 2016 28, 7508-7514.

11 P. G. Rouxhet, in Advances in Contact Angle, Wettability and Adhesion, ed. K. L. Mittal, John Wiley \& Sons, Inc., Hoboken, NJ, USA, 2013, pp. 347-375.

12 J. Landoulsi, M. J. Genet, S. Fleith, Y. Touré, I. Liascukiene, C. Méthivier and P. G. Rouxhet, Applied Surface Science, 2016, 383, 71-83.

13 N. Bridonneau, J. Long, J.-L. Cantin, J. von Bardeleben, D. R. Talham and V. Marvaud, RSC Advances, 2015, 5, 16696-16701.

14 G. Poneti, L. Poggini, M. Mannini, B. Cortigiani, L. Sorace, E. Otero, P. Sainctavit, A. Magnani, R. Sessoli and A. Dei, Chemical Science, 2015, 6, 2268-2274.

15 C. Mathonière, European Journal of Inorganic Chemistry, 2018, 2018, 248-258.

16 D. Garnier, J.-R. Jiménez, Y. Li, J. von Bardeleben, Y. Journaux, T. Augenstein, E. M. B. Moos, M. T. Gamer, F. Breher and R. Lescouëzec, Chemical Science, 2016, 7, 4825-4831.

17 J.-R. Jiménez, J. Glatz, A. Benchohra, G. Gontard, L.-M. Chamoreau, J.-F. Meunier, A. Bousseksou and R. Lescouëzec, Angew. Chem. Int. Ed., , DOI:10.1002/anie.201916199.

18 K. Y. Monakhov, M. Moors and P. Kögerler, in Advances in Inorganic Chemistry, Elsevier, 2017, vol. 69, pp. 251-286.

19 J.-R. Jiménez, M. Tricoire, D. Garnier, L.-M. Chamoreau, J. von Bardeleben, Y. Journaux, Y. Li and R. Lescouëzec, Dalton Transactions, 2017, 46, 15549-15557.

20 A. Hinaut, R. Pawlak, E. Meyer and T. Glatzel, Beilstein J. Nanotechnol., 2015, 6, 1927-1934.

21 C. Méthivier, V. Humblot and C.-M. Pradier, J. Phys. Chem. C, 2016, 120, 27364-27368.

22 T. Jasper-Tönnies, M. Gruber, S. Karan, H. Jacob, F. Tuczek and R. Berndt, J. Phys. Chem. Lett., 2017, 8, 1569-1573.

23 T. Knaak, M. Gruber, S. Puhl, F. Benner, A. Escribano, J. Heck and R. Berndt, J. Phys. Chem. C, 2017, 121, 26777-26784. 
24 A. Saywell, G. Magnano, C. J. Satterley, L. M. A. Perdigão, A. J. Britton, N. Taleb, M. del Carmen Giménez-López, N. R.

Champness, J. N. O'Shea and P. H. Beton, Nat Commun, 2010, 1, 75.

25 P. Erler, P. Schmitt, N. Barth, A. Irmler, S. Bouvron, T. Huhn, U. Groth, F. Pauly, L. Gragnaniello and M. Fonin, Nano Lett., 2015, 15, 4546-4552.

26 M. Shatruk, C. Avendano and K. R. Dunbar, in Progress in Inorganic Chemistry, ed. K. D. Karlin, John Wiley \& Sons, Inc., Hoboken, NJ, USA, 2009, pp. 155-334.

27 S. De, L.-M. Chamoreau, H. El Said, Y. Li, A. Flambard, M.-L. Boillot, S. Tewary, G. Rajaraman and R. Lescouëzec, Frontiers in Chemistry, , DOI:10.3389/fchem.2018.00326.

28 C. D. Wagner and G. E. Muilenberg, Handbook of X-ray Photoelectron Spectroscopy: A Reference Book of Standard Data for Use in X-ray Photoelectron Spectroscopy, Perkin-Elmer, 1979. 29 In NIST X-ray Photoelectron Spectroscopy Database, NIST Standard Reference Database Number 20, National Institute of Standards and Technology, Gaithersburg MD, 2000, p. 20899.

30 Benchohra, Amina, Sorbonne Université, 2019. 